Article

\title{
Cloning, Functional Characterization and Response to Cadmium Stress of the Thioredoxin-like Protein 1 Gene from Phascolosoma esculenta
}

\author{
Jiajie Meng ${ }^{1,+}$, Xinming Gao ${ }^{1,+}$, Shengyu Luo ${ }^{1}$, Chenwen Lin ${ }^{1}$, Chen Du ${ }^{1}$, Congcong Hou ${ }^{1}$, Jianping Wang ${ }^{2}$, \\ Shan Jin ${ }^{1}$, Daojun Tang ${ }^{1}$, Chundan Zhang ${ }^{1}$ and Junquan Zhu ${ }^{1, *}$
}

check for

updates

Citation: Meng, J.; Gao, X.; Luo, S.;

Lin, C.; Du, C.; Hou, C.; Wang, J.; Jin,

S.; Tang, D.; Zhang, C.; et al. Cloning,

Functional Characterization and

Response to Cadmium Stress of the

Thioredoxin-like Protein 1 Gene from

Phascolosoma esculenta. Int. J. Mol. Sci.

2022, 23, 332. https://doi.org/

10.3390/ijms23010332

Academic Editor: Steve Peigneur

Received: 2 November 2021

Accepted: 23 December 2021

Published: 29 December 2021

Publisher's Note: MDPI stays neutral with regard to jurisdictional claims in published maps and institutional affiliations.

Copyright: (C) 2021 by the authors. Licensee MDPI, Basel, Switzerland. This article is an open access article distributed under the terms and conditions of the Creative Commons Attribution (CC BY) license (https:// creativecommons.org/licenses/by/ $4.0 /)$.
1 Key Laboratory of Applied Marine Biotechnology by the Ministry of Education, Ningbo University, Ningbo 315012, China; 534603541@139.com (J.M.); nbugxm4851@163.com (X.G.); 1701091031@nbu.edu.cn (S.L.); $1811075010 @$ nbu.edu.cn (C.L.); 8788182@163.com (C.D.); houcongcong@nbu.edu.cn (C.H.); jinshan@nbu.edu.cn (S.J.); tangdaojun@nbu.edu.cn (D.T.); zhangchundan@nbu.edu.cn (C.Z.)

2 Ningbo Academy of Oceanology and Fisheries, Ningbo 315012, China; wjping805@126.com

* Correspondence: zhujunquan@nbu.edu.cn

$\dagger$ These authors contributed equally to this work.

\begin{abstract}
Cadmium (Cd) is a heavy metal toxicant and is widely distributed in aquatic environments. It can cause excessive production of reactive oxygen species (ROS) in the organism, which in turn leads to a series of oxidative damages. Thioredoxin (Trx), a highly conserved disulfide reductase, plays an important role in maintaining the intracellular redox homeostasis in eukaryotes and prokaryotes. Phascolosoma esculenta is an edible marine worm, an invertebrate that is extensively found on the mudflats of coastal China. To explore the molecular response of Tr $x$ in mudflat organisms under Cd stress, we identified a new Trx isoform (Trx-like protein 1 gene) from P. esculenta for the first time, designated as PeTrxl. Molecular and structural characterization, as well as multiple sequence and phylogenetic tree analysis, demonstrated that PeTrxl belongs to the Trx superfamily. PeTrxl transcripts were found to be ubiquitous in all tissues, and the highest expression level occurred in the coelomic fluid. Exposure to three sublethal concentrations of $\mathrm{Cd}$ resulted in the upregulation and then downregulation of PeTrxl expression levels over time in coelomic fluid of P. esculenta. The significant elevation of PeTrxl expression after 12 and $24 \mathrm{~h}$ of $\mathrm{Cd}$ exposure at 6 and $96 \mathrm{mg} / \mathrm{L}$, respectively, might reflect its important role in the resistance to Cd stress. Recombinant PeTrxl ( $r P e \operatorname{Trxl}$ ) showed prominent dose-dependent insulin-reducing and ABTS free radical-scavenging abilities. After exposure to $96 \mathrm{mg} / \mathrm{L} \mathrm{Cd}$ for $24 \mathrm{~h}$, the ROS level increased significantly in the coelomic fluid, suggesting that $\mathrm{Cd}$ induced oxidative stress in P. esculenta. Furthermore, the injection of $r P e \operatorname{Trxl}$ during Cd exposure significantly reduced the ROS in the coelomic fluid. Our data suggest that $P e T r x l$ has significant antioxidant capacity and can protect $P$. esculenta from $\mathrm{Cd}$-induced oxidative stress.
\end{abstract}

Keywords: thioredoxin-like protein 1; Phascolosoma esculenta; cadmium; coelomic fluid

\section{Introduction}

Cadmium (Cd), an unessential metal element in organisms, is widely distributed in aquatic environments [1]. Current studies have found that the molecular mechanisms of Cd toxicity are diverse, including oxidative damage [2,3], apoptosis [4,5], autophagy [6], DNA damage $[7,8]$ and inhibition of energy metabolism $[9,10]$, with complex relationships existing among them [11].

$\mathrm{Cd}^{2+}$ in organisms can bind with the sulfhydryl groups of antioxidant enzymes, resulting in their reduced activity or inactivation and indirectly increasing intracellular levels of reactive oxygen species (ROS) $[12,13]$. Moreover, generating $\mathrm{OH}$ radicals via the Fenton reaction between $\mathrm{Cd}^{2+}$ and hydrogen peroxide directly leads to an increase in intracellular 
levels of ROS [14]. The excessive ROS can cause lipid peroxidation of the cell membrane, leading to oxidative damage or apoptosis $[15,16]$. To minimize the adverse effects of ROS, developing pathways through which excess ROS are scavenged is necessary for organisms. Eukaryotes and prokaryotes have integrated antioxidant systems to resist the harmful effects of ROS, including enzymatic antioxidants (such as thioredoxin (Trx), peroxidase, and catalase) or non-enzymatic antioxidants (such as glutathione (GSH) and vitamin C) [17].

The Trx system, composed of Trx, Trx reductase, and NADPH [18], is one of the major antioxidant systems involved in maintaining the intracellular reducing status [19-21]. Trx is a small-molecular weight protein $(12 \mathrm{kDa})$ and exists ubiquitously in eukaryotes and prokaryotes [22]. Moreover, its redox active site, a Cys- $X_{1}-X_{2}-C y s\left(C X_{1} X_{2} C\right)$ motif, plays a reducing role by converting dithiol/disulfide bonds between sulfhydryl groups on two cysteine residues in the active site and the disulfide bond of the target protein [23]. Emerging evidence has shown that Trx plays an important role in DNA replication [24], inhibition of apoptosis [25], and maintenance of cellular redox homeostasis [26].

Previous studies have identified many various types of Trx isoforms [27]. Trx-like protein 1 (Trxl; $32 \mathrm{kDa}$ ), a member of the Trx superfamily, consists of an N-terminal Trx domain and a C-terminal proteasome-interacting Trx (PITH) domain. However, functional research on Trxl is still in its infancy compared to that for Trx. The Trx domain of Trxl can perform a classical Trx function, repairing oxidatively damaged proteins [28] and scavenging ROS [29] through redox shifts in the $\mathrm{CX}_{1} \mathrm{X}_{2} \mathrm{C}$ active site. In addition, the PITH domain is a $26 \mathrm{~S}$ proteasome module is involved in the degradation of intracellular proteins [30]. At present, Trxl has been investigated in various aquatic organisms, including Apostichopus japonicus [31], Hippocampus abdominalis [32], and Larimichthys crocea [33], with particular focus placed on the function of immune stimulation. However, its roles in regulating intracellular redox homeostasis during $\mathrm{Cd}$ stress remain unknown in mudflat organisms.

Phascolosoma esculenta, belonging to the phylum Sipuncula and the class Phascolosomatidea, is an edible marine invertebrate that resembles a worm and is widely found in the intertidal mudflats of coastal China, living in burrows and feeding on benthic algae and organic debris. As the lives of benthic animals are relatively stable, they are easy to count, and since they are sensitive to environmental changes, they can better reflect the pollution status of water and substrates in the environments of their habitats. Furthermore, P. esculenta has a high tolerance to heavy metals [34], and thus, it is a good indicator organism of heavy metal pollution in marine mudflats.

To our knowledge, studies on the response of marine mudflat invertebrate $\operatorname{Tr} x l$ to heavy metals are lacking to date. In the present study, to better understand the role of mudflat organism Trxl in the detoxification of ROS induced by Cd stress, we cloned and characterized a Trxl gene (designated as PeTrxl) from P. esculenta. Furthermore, the tissue distribution and temporal expression profile of PeTrxl following exposure to $\mathrm{Cd}$ were examined. Finally, PeTrxl was reconstituted in Escherichia coli for in vitro activity assays and in vivo functional tests. This study indicated that $P e T r x l$ is involved in the scavenging of ROS induced by $\mathrm{Cd}$ and provides important insights into the role of antioxidant systems during heavy metal-induced oxidative stress resistance.

\section{Results}

\subsection{PeTrxl Full-Length cDNA Cloning and Sequence Analysis}

Full-length PeTrxl cDNA from P. esculenta (GenBank accession No. MW767160) was $1463 \mathrm{bp}$ in length, which included an $861 \mathrm{bp}$ ORF encoding 286 aa, a $69 \mathrm{bp} 5^{\prime}$ untranslated region (UTR), and a $533 \mathrm{bp} 3^{\prime}$ UTR with two polyadenylation signals (ATTAAA) (Figure 1A). The predicted molecular weight and isoelectric point of the PeTrxl protein were $31.62 \mathrm{kDa}$ and 4.97, respectively. SignalP-5.0 tool analysis revealed that a signal peptide was absent in the PeTrxl sequence. According to the protein subcellular localization prediction, PeTrxl was located in the cytosol and nucleus.

The Cys-Gly-Pro-Cys (CGPC) motif, located at the beginning of the second $\alpha$-helix, is a typically conserved active site in $\operatorname{Trx}($ Figure $1 \mathrm{~A}, \mathrm{~B})$. The PeTrxl protein sequence struc- 
ture contained two conserved domains, namely an N-terminal Trx domain (10-103 aa) and a C-terminal PITH domain (129-265 aa; Figure 1A,B). The tertiary structure of the predicted Trx domain was composed of four $\beta$-sheets sandwiched by four $\alpha$-helices, forming an $\alpha 1 \beta 1 \alpha 2 \beta 2 \alpha 3 \beta 3 \beta 4 \alpha 4$ structure (Figure 1B). The PITH domain was a general $26 S$ proteasome-interacting module.
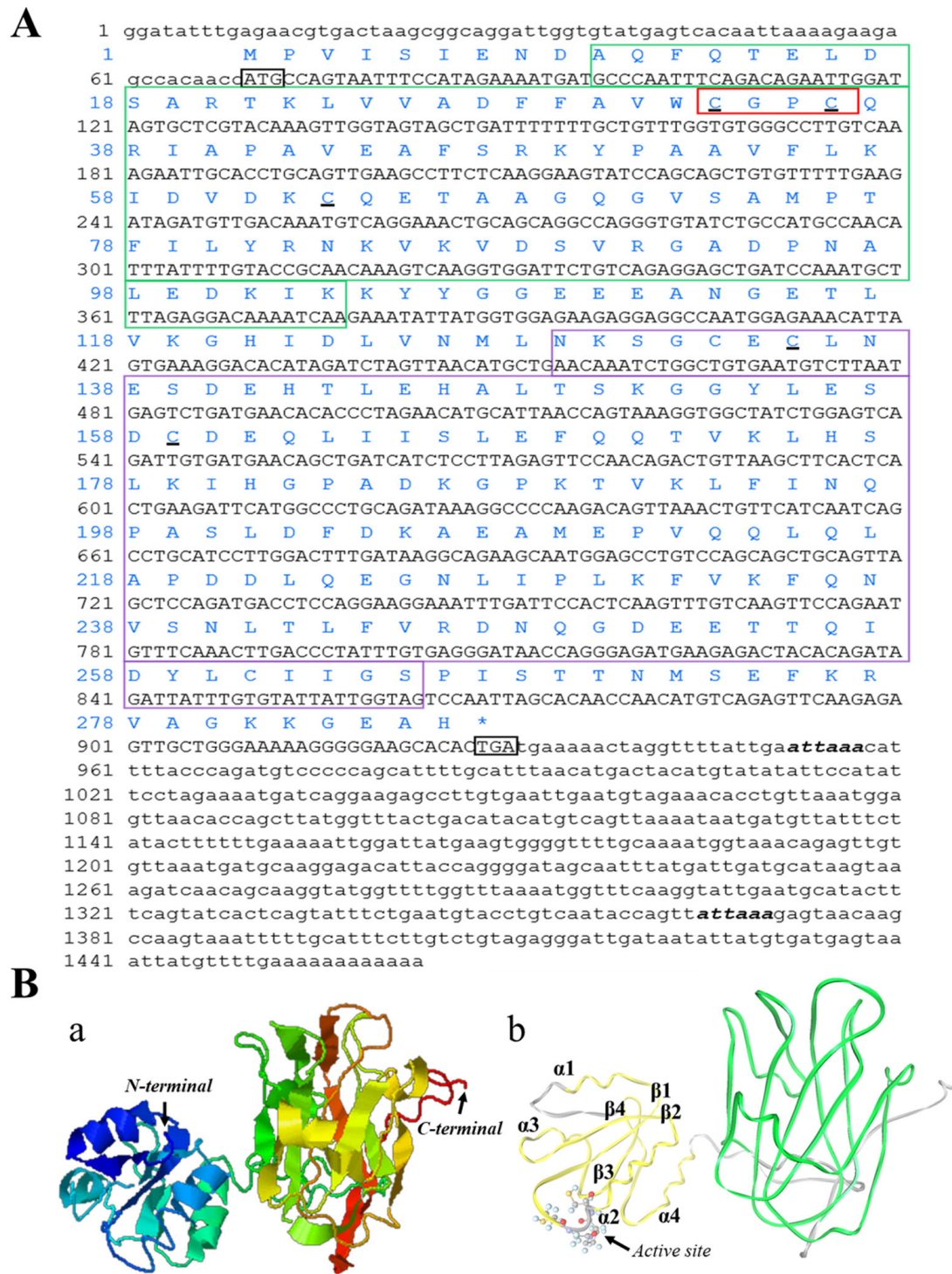

Figure 1. The completed cDNA, deduced amino acid sequence, and the 3D structure of PeTrxl. (A) The completed cDNA sequence and deduced amino acid sequence of PeTrxl. Start and stop codons are indicated via a black box. Regions indicated by green and purple boxes encode the Trx (10-103 aa) and PITH (129-265 aa) domains, respectively. The catalytic active site ${ }^{33}$ CGPC ${ }^{36}$ is marked with a red box. The remaining three conserved cysteine residues ( $\mathrm{Cys}_{63}, \mathrm{Cys}_{135}$, and $\mathrm{Cys}_{159}$ ) are underlined via a black line. Polyadenylation signals are marked in bold and italics. (B) The 3D structure of the PeTrxl protein. (a) The N- and C-termini of PeTrxl. (b) The yellow and green structures denote the Trx and PITH domains, respectively.

\subsection{PeTrxl Sequence Alignment and Phylogenetic Analysis}

The result of the multiple sequence alignment of PeTrxl and Trxl amino acid sequences from other species is shown in Figure 2A; Trxl amino acid sequences of various species are highly homologous. The identities of the PeTrxl amino acid sequence with Trxl amino acid sequences from Homo sapiens, Mus musculus, Gallus gallus, Xenopus tropicalis, Danio rerio, 
Daphnia pulex, Aplysia californica, Crassostrea virginica, and Nematostella vectensis were 51.2, $51.6,52.2,50.2,50.5,61.5,65.5,65.6$, and $61.8 \%$, respectively. The highest homology to PeTrxl was found with that of Mollusca (C. virginica, 65.6\% identity). As the $\mathrm{CX}_{1} \mathrm{X}_{2} \mathrm{C}$ motif is a typical redox-active site in the Trx family, it was present in all the aligned sequences. The CGPC motif, which is generally found in the animal kingdom, was observed in P. esculenta. In addition, three conserved cysteine residues were found in the Trxl amino acid sequence alignment of the 10 species. The phylogenetic tree constructed using the neighbor-joining tree method showed that Trxl in invertebrates and vertebrates is clustered into two branches (Figure 2B). PeTrxl was clustered with Mollusca Trxl in the invertebrate branch, closest to Trxl from Pomacea canaliculata and A. californica in the selected species.
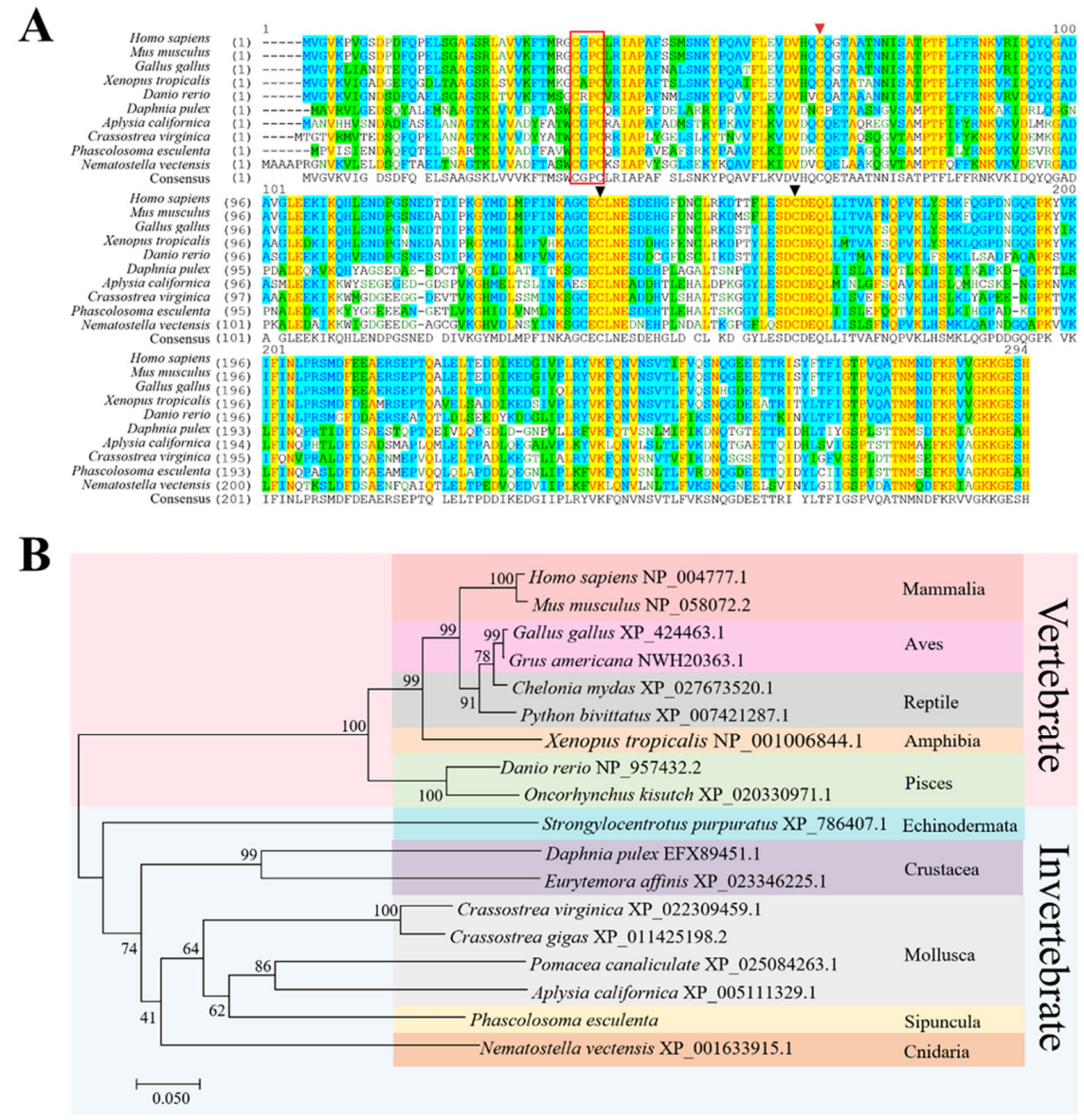

Figure 2. The Multiple sequence alignment and phylogenetic analysis of PeTrxl. (A) Multiple sequence alignment of $P e \operatorname{Trxl}$ and Trxl amino acid sequences from other species (H. sapiens NP_004777.1, 51.2\% identity; M. musculus NP_058072.2, 51.6\% identity; G. gallus XP_424463.1, 52.2\% identity; X. tropicalis NP_001006844.1,50.2\% identity; D. rerio NP_957432.2, 50.5\% identity; D. pulex EFX89451.1, 61.5\% identity; A. californica XP_005111329.1, 65.5\% identity; C. virginica XP_022309459.1,65.6\% identity; N. vectensis XP_001633915.1,61.8\% identity). The same amino acid residues are shaded in yellow. Blue regions indicate amino acid residues with a similarity greater than $50 \%$; green regions represent lower similarity. The red box indicates the conserved catalytic active site $\mathrm{CX}_{1} \mathrm{X}_{2} \mathrm{C}$. Red and black triangles indicate conserved cysteine residues in Trx and PITH domains, respectively. (B) Phylogenetic tree analysis of the PeTrxl amino acid sequence. Mega 7.0 software was used to construct a phylogenetic tree; the number at each branch represents the percentage value obtained after 1000 bootstrap replicates were performed. The two branches in the phylogenetic tree are vertebrates, including Mammalia, Aves, Reptilia, Amphibia, and Pisces and invertebrates, including Echinodermata, Crustacea, Mollusca, Sipuncula, and Cnidaria. 


\subsection{Tissue Distribution of PeTrxl mRNA}

Semi-quantitative reverse transcription PCR (RT-PCR) and real-time quantitative PCR (RT-qPCR) were used to detect the transcription levels of PeTrxl mRNA in different tissues (Figure 3). As shown in Figure 3, PeTrxl mRNA was widely distributed in tissues and could be detected in the coelomic fluid, intestine, body wall, retractor muscle, and nephridium. In addition, the expression level of PeTrxl mRNA in the coelomic fluid was significantly higher than that in other tissues, whereas its expression was the lowest in the nephridium.
A
B
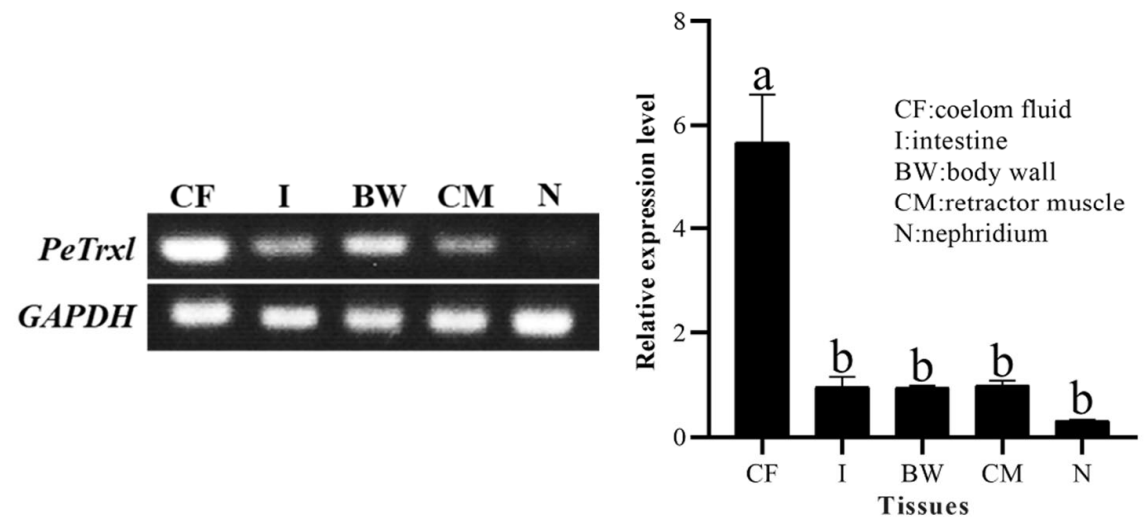

Figure 3. Distribution of PeTrxl mRNA in different tissues. (A) RT-PCR detection. (B) RT-qPCR detection. The GAPDH gene was used as an internal reference; data are expressed as the mean $\pm \mathrm{SD}$ $(n=3)$; different letters indicate significant difference $(p<0.05)$.

\subsection{PeTrxl mRNA Expression Differences in the Coelomic Fluid following Cd Stress}

The temporal expression levels of PeTrxl mRNA in the coelomic fluid of P. esculenta, following exposure to different concentrations of $\mathrm{Cd}$, are shown in Figure 4. PeTrxl mRNA expression levels were significantly different in Cd-exposed samples, compared to those in control groups. The control groups maintained a stable expression level of PeTrxl throughout the experiment. In contrast, the expression levels of PeTrxl increased 1.85- and 1.30-fold after exposure to $6 \mathrm{mg} / \mathrm{L}$ of Cd for 12 and $24 \mathrm{~h}$, respectively. Subsequently, PeTr $x \mathrm{l}$ mRNA levels decreased 1.78-, 2.22-, and 2.11-fold after 48, 72, and 96 h, respectively. PeTr $x \mathrm{l}$ mRNA levels decreased by 1.44- and 1.71-fold after 72 and 96 h, respectively, following exposure to $24 \mathrm{mg} / \mathrm{L}$ of Cd. No significant change in PeTrxl mRNA levels was observed after 12, 24, and $48 \mathrm{~h}$ of exposure to $24 \mathrm{mg} / \mathrm{L}$ of $\mathrm{Cd}$. Following exposure to Cd levels under $96 \mathrm{mg} / \mathrm{L}$, PeTrxl mRNA expression levels increased 1.5- and 1.38-fold at 12 and $24 \mathrm{~h}$, respectively, and decreased 2.47-fold at $96 \mathrm{~h}$. PeTrxl mRNA levels peaked $12 \mathrm{~h}$ after exposure to $6 \mathrm{mg} / \mathrm{L}$ of $\mathrm{Cd}$. 


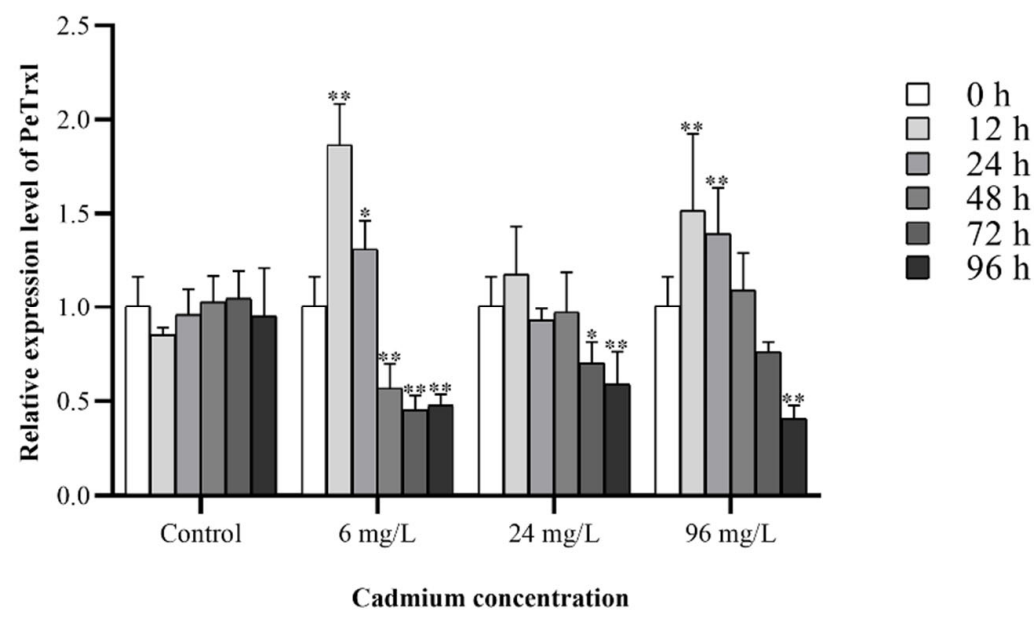

Figure 4. The relative expression level of PeTrxl mRNA in the coelomic fluid of P. esculenta following Cd stress. Expression characterization of PeTrxl mRNA was performed using RT-qPCR. Data are expressed as the mean $\pm \mathrm{SD}(n=4)$. Significant differences between the Cd-treated group and the control group are shown with an asterisk $\left({ }^{*} p<0.05 ;{ }^{* *} p<0.01\right)$.

\subsection{PeTrxl Expression and Purification}

As shown in Figure 5A, we transfected E. coli cells with the PeTrxl gene, also successfully inducing its expression. SDS-PAGE (sodium dodecyl sulfate polyacrylamide gel electrophoresis) analysis revealed that the recombinant $P e \operatorname{Tr} x l(r P e \operatorname{Tr} x l)$ was present in the inclusion bodies. A single band of purified $r P e \operatorname{Trxl}$ was approximately $31.62 \mathrm{kDa}$, which was consistent with the theoretical value predicted by the ProtParam tool. Next, purified $r P e T r x l$ was renatured using the dialysis refolding method; the concentration of refolded $r P e \operatorname{Trxl}$ was $956 \mu \mathrm{g} / \mathrm{mL}$, as measured using Bradford's method.

A

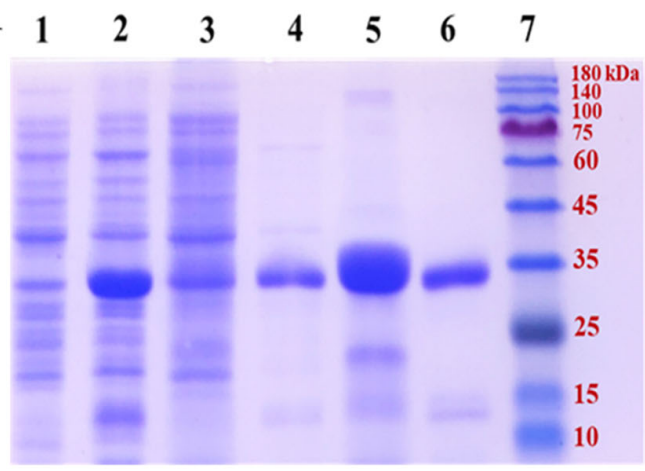

$\mathrm{B}$

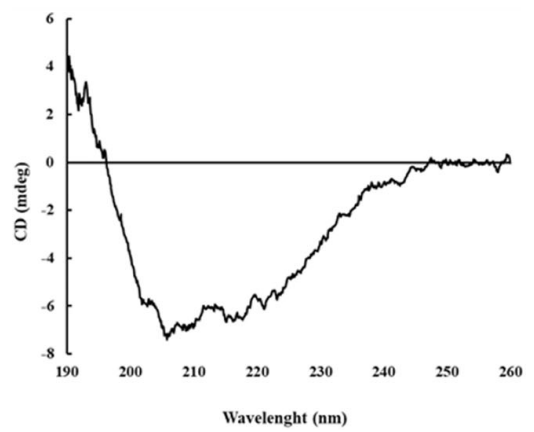

Figure 5. (A) SDS-PAGE analysis of recombinant PeTrxl. $r P e \operatorname{Trxl}$ was separated using 10\% SDS-PAGE; protein bands were visualized after staining with Coomassie Brilliant Blue R250. Line 1: lysate of E. coli (pET28a-PeTrxl) without induction; Line 2: lysate of E. coli (pET28a-PeTrxl) induced by IPTG; Line 3: supernatant of lysate; Line 4: pellet of lysate; Line 5: purified $r P e \operatorname{Trxl}$; Line 6: refolded $r P e \operatorname{Trxl}$; Line 7: protein marker. (B) Circular dichroism spectral analysis of refolded $r P e \operatorname{Trxl}$.

The results of the circular dichroism spectroscopy indicated that the refolded $r P e \operatorname{Trxl}$ has a significant secondary structure absorption spectrum (Figure 5B). The percentage of secondary structure is $13.5 \% \alpha$-helices, $39.5 \% \beta$-sheets, $8.9 \% \beta$-turns, and $38.1 \%$ random coils (Table 1). 
Table 1. Secondary structure of $r P e T r x l$.

\begin{tabular}{cc}
\hline Type & Percentage \\
\hline$\alpha$-helix & $13.5 \%$ \\
$\beta$-sheet & $39.5 \%$ \\
$\beta$-turn & $8.9 \%$ \\
Random coil & $38.1 \%$ \\
\hline
\end{tabular}

\subsection{In Vitro Refolded rPeTrxl Activity Assay}

\subsubsection{Insulin Disulfide Reduction Assay}

The specific reducing activity of $r P e \operatorname{Trxl}$ was investigated using an insulin disulfide reduction assay (Figure 6A). The results showed that in the presence of dithiothreitol (DTT), the disulfide bonds between the A and B chains of insulin were broken in the experimental group with $r P e$ Trxl, with the precipitation caused by $\mathrm{B}$ chain aggregation increasing the absorbance $(\mathrm{Ab})$ of the reaction system at $650 \mathrm{~nm}$. In addition, increasing the concentration and reaction time resulted in significant increases in the $\mathrm{Ab}$, indicating that the reducing activity of $r P e \operatorname{Trxl}$ was time- and dose-dependent. In contrast, owing to a lack of $r P e \operatorname{Trxl}$, the $\mathrm{Ab}$ increased only slightly in the control group during the experiment; the negative control group did not exhibit a change in $\mathrm{Ab}_{650}$.

A

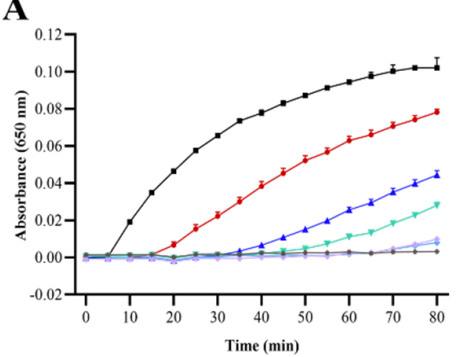

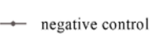

$\rightarrow$ negative

- $\quad 5 \mu \mathrm{g} / \mathrm{mL}$

$\rightarrow 15 \mu \mathrm{g} / \mathrm{mL}$

$\rightarrow 30 \mu \mathrm{g} / \mathrm{mL}$

$\rightarrow 60 \mu \mathrm{gg} / \mathrm{mL}$

$\rightarrow 120 \mu \mathrm{g} / \mathrm{m}$
B

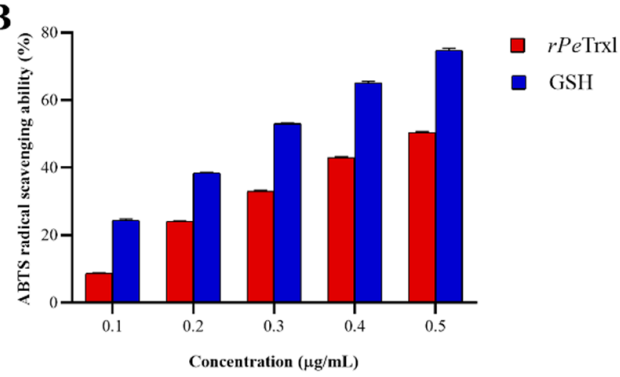

Figure 6. $r P e T r x l$ redox activity detection. (A) $r P e \operatorname{Trxl}$ insulin disulfide reduction assay. The final concentrations of $r P e \operatorname{Trxl}$ in the reaction mixture were $0,5,15,30,60$, and $120 \mu \mathrm{g} / \mathrm{mL}$. The absorbance $(\mathrm{Ab} ; 650 \mathrm{~nm})$ of the reaction mixture was monitored following the addition of DTT. The reaction system without DTT and $r P e \operatorname{Trxl}$ was the negative control. Data are presented as the mean $\pm \mathrm{SD}$ $(n=3)$. (B) ABTS radical scavenging assay of $r P e T r x l$. Different concentrations of GSH $(0.1,0.2,0.3$, 0.4 , and $0.5 \mu \mathrm{g} / \mathrm{mL})$ were used as the positive control. Data are presented as the mean $\pm \mathrm{SD}(n=3)$.

\subsubsection{ABTS Radical-Scavenging Assay}

The ABTS (2,2'-azino-bis(3-ethylbenzothiazoline-6-sulfonic acid)) radical is a stable organic radical. The ABTS radical-scavenging rate of $r P e T r x l$ corresponded to its antioxidant capacity. As shown in Figure 6B, the ABTS radical scavenging rates of $r P e \operatorname{Trxl}$ and GSH were positively correlated with their concentrations. Both $r P e \operatorname{Trxl}$ and GSH had the highest ABTS radical-scavenging rates at $0.5 \mathrm{mg} / \mathrm{mL}$, specifically 50.35 and $74.71 \%$, respectively, at which point, the gap between them was also the smallest. In addition, the $\mathrm{IC}_{50}$ of the ABTS radical-scavenging ability of $r P e \operatorname{Trxl}$ and GSH was 0.488 and $0.255 \mathrm{mg} / \mathrm{mL}$, respectively; higher $\mathrm{IC}_{50}$ values indicated a lower $\mathrm{ABTS}$ radical-scavenging ability. These results illustrate that $r P e \operatorname{Trxl}$ has a high ability to scavenge ABTS radicals.

\subsection{In Vivo Refolded rPeTrxl Activity Assay}

To further investigate the redox function of $r P e \operatorname{Trxl}$ under Cd stress, it was injected into P. esculenta. As shown in Figure 7, ROS levels in the coelomic fluid of P. esculenta were significantly increased in the Cd-treated group and the Cd-treated groups injected with BSA and PBS, respectively, compared with those in the blank control and $r P e T r x l-i n j e c t i o n$ groups. However, no significant differences were observed in ROS levels between the blank control and $r P e T r x l$-injection groups. 


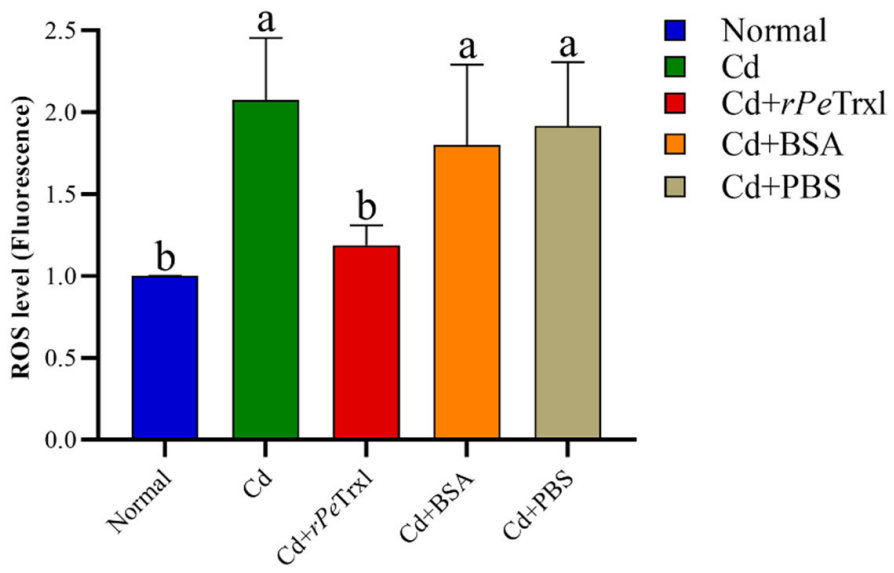

Figure 7. In vivo reactive oxygen species (ROS) level variation in P. esculenta following $r P e \operatorname{Trxl}$ injection. Flow cytometry was used to monitor the fluorescence intensity of ROS in coelomic fluid cells. The normal group, without exposure to $\mathrm{Cd}$, served as the blank control, whereas the Cd-treated group was the positive control. Cd exposure groups injected with BSA and PBS, respectively, served as control groups. Significant differences are indicated via different letters $(p<0.05)$. Data are presented as the mean $\pm \operatorname{SD}(n=9)$.

\section{Discussion}

\subsection{Characterization of PeTrxl}

This is the first study to clone and identify the complete cDNA sequence of PeTrxl from P. esculenta. The CGPC motif, a typical redox active site belonging to Trx, was found in the PeTrxl amino acid sequence (Figure 1A), which is consistent with Trxl from H. sapiens [35], A. japonicus [31], and Strongyloides Ratti [36]. Our results indicated that PeTrxl contained two conserved domains, namely an N-terminal Trx domain and a C-terminal PITH domain (Figure 1A). The structure of the Trx domain consists of four $\beta$-sheets surrounded by four $\alpha$-helices [32,37,38], in the formation of $\alpha 1 \beta 1 \alpha 2 \beta 2 \alpha 3 \beta 3 \beta 4 \alpha 4$ (Figure 1B). The active site (CGPC) motif of the Trx domain, located at the beginning of the second $\alpha$-helix, maintains intracellular redox homeostasis via the exchange reaction of thiol/disulfide bonds between two cysteine residues [23]. In addition, the PITH domain, a general $26 \mathrm{~S}$ proteasome-interacting module, is able to bind to $19 \mathrm{~S}$ regulatory complexes (the components of the $26 \mathrm{~S}$ proteasome) in mammals to participate in protein deubiquitination and degradation [30,39,40]; this domain exists in all Trxl proteins [36]. The amino acid sequence of Trxl is relatively evolutionarily conserved. Multiple sequence alignment indicated that $P e$ Trxl possessed the highest similarity $(65.6 \%)$ with Trx 1 of $C$. virginica, whereas similarities with those of all species in Figure 2A ranged from 50 to $65.6 \%$. Meanwhile, phylogenetic tree analysis revealed that $P e \operatorname{Tr} x \mathrm{l}$ had the highest homology with Mollusca ( $P$. canaliculata and A. californica) Trxl (Figure 2B). Based on these results, we identified PeTrxl as a new member of the Trx superfamily.

\subsection{Tissue Distribution of PeTrxl and Its Expression during Cd Stress}

$\mathrm{Cd}$ is generally a peroxide inducer that causes oxidative damage to cells by binding to the thiol groups of enzymes, thereby causing a change in the enzyme spatial conformation and leading to a decrease in enzyme activity [12,41,42]. To resist the oxidative damage caused by ROS, organisms have developed a complete antioxidant system [17]. Trx is an important antioxidant in organisms [19]. At present, only a few reports have investigated variations in $\operatorname{Tr} x$ gene expression following Cd exposure in aquatic animals. In this study, the tissue distribution of $P e T r x l$, as well as its response to different $\mathrm{Cd}$ concentrations and exposure times, was investigated.

Extensive research has revealed that Trxl is abundant, stable, and ubiquitously expressed in the cells of all examined vertebrate and invertebrate tissues $[30,31,33,43]$. Similarly, PeTrxl mRNA was detected in all tissues examined in this study, suggesting that this 
gene might be involved in an important physiological function. However, tissues with high expression levels of Tr $x l$ mRNA were determined to be different in various species. For example, in the big-belly seahorse H. abdominalis [32] and the Chinese honeybee Apis cerana cerana [44], the highest expression levels of $\operatorname{Tr} x \mathrm{l}$ mRNA were found in the muscle and epidermis, respectively. In P. esculenta, the highest and lowest PeTrxl mRNA expression levels were detected in the coelomic fluid and nephridium, respectively. Coelomic fluid, mainly consisting of blood cells, granular cells, and germ cells [45], accounts for approximately half of the body weight of P. esculenta and is important for immunity and energy metabolism [46-48]; thus, the expression level of PeTrxl in coelomic fluid during $\mathrm{Cd}$ stress was examined. Previous studies have demonstrated that low concentrations and short periods of $\mathrm{Cd}$ stress can activate the antioxidant system in organisms, enhancing the scavenging capacity for ROS; however, high concentrations and long periods of Cd stress exceed the detoxification capacity of the antioxidant system, thereby causing oxidative damage $[7,49,50]$. In our study, we found that PeTrxl mRNA expression levels correlated with the concentration and duration of $\mathrm{Cd}$ exposure (Figure 4), showing significant upregulation in both the low and high concentration $(6 \mathrm{mg} / \mathrm{mL}$ and $96 \mathrm{mg} / \mathrm{mL})$ groups after 12 and $24 \mathrm{~h}$ of $\mathrm{Cd}$ exposure and indicating that PeTrxl mRNA is sensitive to Cd stress in the early stages. PeTrxl mRNA expression was upregulated to reduce and repair oxidized or damaged proteins [31,32]; similar phenomena have been reported in previous studies [51-53]. However, PeTrxl mRNA expression levels were significantly downregulated in the three $\mathrm{Cd}$ concentration groups, compared with those in the control group, after $96 \mathrm{~h}$ of $\mathrm{Cd}$ exposure, potentially explaining the antioxidant system damage caused by $\mathrm{Cd}$ accumulation over time [7]. Alternatively, the expression level of PeTrxl began to decrease gradually after $12 \mathrm{~h}$, which may be related to the activation of other antioxidant and detoxification genes $[52,54,55]$. These genes have important functions in the maintenance of redox homeostasis, resulting in a weakened requirement for PeTrxl. It is worth mentioning that the expression level of PeTrxl did not change significantly at 12 and $24 \mathrm{~h}$ under moderate stress $(24 \mathrm{mg} / \mathrm{mL})$. Although the exact cause remains unclear, we speculate that PeTrxl may be an extremely $\mathrm{Cd}$-sensitive gene that is activated and involved in scavenging ROS before $12 \mathrm{~h}$, after which its expression level begins to decrease with the activation of other antioxidant systems. These results suggest that PeTrxl is an important functional gene and involved in the detoxification of P. esculenta at the early stages of Cd stress. Additionally, PeTrxl can be used as a biomarker to study the detoxification mechanism of invertebrate mudflat organisms under heavy metal exposure.

\subsection{Function of PeTrxl in Cd Stress}

Trx, an important functional protein, maintains cellular redox homeostasis and has multiple intracellular and extracellular functions [56,57]. At present, in aquatic animals, many studies have focused on investigating the Trx function associated with antibacterial and antiviral immunity; few studies have reported the function of Trx in resisting heavy metal stress. In this study, the activity of $r P e \operatorname{Trxl}$ was detected in vitro, and its function in Cd stress was further examined.

In our study, the activity of $r P e \operatorname{Trxl}$ was investigated using insulin disulfide reduction [58] and ABTS radical scavenging assays. The results of the former assay showed that insulin was reduced by $r P e T r x l$, with the $\mathrm{Ab}$ then increasing at $650 \mathrm{~nm}$ as precipitation proceeded (Figure 6A). In addition, the reduction efficiency of $r P e \operatorname{Trxl}$ increased with time in a dose-dependent manner, a pattern demonstrated in previous studies $[31,33,36]$. However, a slight change in $\mathrm{Ab}$ was observed in the control group during the experiment. Interestingly, a similar result was detected in Haliotis discus discus [59], Trichoderma reesei [60], and Spodoptera litura [61]. This might be a result of the slow reduction of insulin mediated by DTT. The ABTS radical scavenging assay is typically used to detect the antioxidant capacity of antioxidants. Our results showed that the ABTS radical scavenging efficiency of $r P e T r x l$ increased in a dose-dependent manner and was lower than that of GSH (Figure 6B). Previous studies have revealed that Trx can effectively scavenge hydroxyl and DPPH free 
radicals $[32,62]$. Based on these results, we infer that PeTrxl is a protein with antioxidant activity that might perform its function by either reducing disulfide bonds in proteins or reacting directly with ROS.

Moreover, to further investigate the function of $P e \operatorname{Trxl}$, the role of $r P e \operatorname{Trxl}$ in Cd stress was investigated, for the first time, by injecting the recombinant protein in vivo. The results showed that levels of ROS in the coelomic fluid cells of P. esculenta were significantly upregulated after $24 \mathrm{~h}$ of Cd stress $(96 \mathrm{mg} / \mathrm{L})$; however, this level was significantly lower in the group injected with $r P e \operatorname{Trxl}$ than in the other experimental groups (Figure 7). This difference could be caused by the involvement of $r P e \operatorname{Trxl}$ in the scavenging of ROS and demonstrate that PeTrxl can perform its antioxidant function in the extracellular space. Notably, although Trx lacks a signal peptide, it can be secreted into the extracellular compartment via a non-classical pathway [63] and protect cells in response to oxidative stress and inflammation [64]. Similar to Trx, Trxl can also be released into the extracellular space to exert its effects [36]. These results suggest that PeTrxl is a powerful antioxidant protein that can effectively scavenge ROS. Additionally, the injection of $r P e$ Trxl may be an effective way of antioxidant.

\section{Materials and Methods}

\subsection{Experimental Animals, Treatments, and Sampling}

Healthy P. esculenta (3.9 $\pm 0.7 \mathrm{~g}$ ) were obtained from Xizhou of Ningbo (Zhejiang, China); they were acclimatized in $32 \mathrm{~cm} \times 21 \mathrm{~cm} \times 20 \mathrm{~cm}$ constantly aerated plastic tanks with $28 \%$ filtered seawater at $22 \pm 0.5^{\circ} \mathrm{C}$ for $24 \mathrm{~h}$. Individuals were randomly and evenly distributed across 12 tanks, and a $\mathrm{CdCl}_{2}$ solution was prepared with $\mathrm{CdCl}_{2} \cdot 2.5 \mathrm{H}_{2} \mathrm{O}$ (Sinopharm, Shanghai, China). Four Cd-exposure concentrations, including 0, 6, 24, and $96 \mathrm{mg} / \mathrm{L}$, corresponding to $0,1 / 32,1 / 8$, and $1 / 2$ of the $\mathrm{LC}_{50}$ value, respectively, based on our previous studies (pre-test) investigating the effect of $\mathrm{Cd}^{2+}$ exposure on P. esculenta, were used in the toxicity experiment. Three replicate tanks were used for each treatment. Following 0,12, 24, 48, 72, and $96 \mathrm{~h}$ of exposure, coelomic fluids (mainly including blood cells, granular cells, and germ cells) were collected from six randomly selected individuals treated with each concentration. The coelomic fluid, body wall, intestine, retractor muscle, and nephridium were sampled for tissue distribution detection. All samples were immediately frozen in liquid nitrogen upon dissection and stored at $-80^{\circ} \mathrm{C}$. All experimental procedures were approved by the Animal Care and Use Committee of Ningbo University (Ningbo, China).

\subsection{Full-Length cDNA Cloning of PeTrxl}

First, we obtained a partial cDNA sequence (GenBank accession No. OL757513) of PeTrxl from transcriptome data. Next, specific primers (Table 2) were designed using Primer Premier 5.0 software, and the cDNA sequence was verified by sequencing the ORF fragment. Touchdown PCR parameters were as follows: $94{ }^{\circ} \mathrm{C}$ for $5 \mathrm{~min}$; 10 cycles of $94{ }^{\circ} \mathrm{C}$ for $30 \mathrm{~s}, 59^{\circ} \mathrm{C}$ for $30 \mathrm{~s}$ (decreased by $0.5^{\circ} \mathrm{C} /$ cycle), and $72{ }^{\circ} \mathrm{C}$ for $50 \mathrm{~s} ; 30$ cycles of $94{ }^{\circ} \mathrm{C}$ for $30 \mathrm{~s}, 54{ }^{\circ} \mathrm{C}$ for $30 \mathrm{~s}$, and $72{ }^{\circ} \mathrm{C}$ for $45 \mathrm{~s}$; and a final extension at $72{ }^{\circ} \mathrm{C}$ for $10 \mathrm{~min}$. PCR products were separated on $1 \%$ agarose gels, and the target bands were obtained by purifying the gel products with a DNA Gel Extraction Kit (BioTeke, Beijing, China). Next, purified products were ligated into the PMD-18T vector and transformed into competent cells (E. coli DH5 $\alpha$ ). Positive clones were identified using PCR and M13F/R primers and subsequently sequenced by GENEWIZ (Suzhou, Jiangsu, China).

Based on the aforementioned intermediate fragment, $5^{\prime}$ and $3^{\prime}$ RACE primers (Table 2) were designed for the rapid amplification of cDNA ends (RACE). Touchdown PCR reaction conditions for $5^{\prime}$ and $3^{\prime}$ RACE were as follows: $94{ }^{\circ} \mathrm{C}$ for $5 \mathrm{~min} ; 8$ cycles at $94{ }^{\circ} \mathrm{C}$ for $30 \mathrm{~s}$, $69{ }^{\circ} \mathrm{C} / 63{ }^{\circ} \mathrm{C}$ for $30 \mathrm{~s}$ (decreased by $0.5^{\circ} \mathrm{C} /$ cycle), and $72{ }^{\circ} \mathrm{C}$ for $40 \mathrm{~s} / 1 \mathrm{~min}$; 30 cycles at $94{ }^{\circ} \mathrm{C}$ for $30 \mathrm{~s}, 65{ }^{\circ} \mathrm{C} / 59{ }^{\circ} \mathrm{C}$ for $30 \mathrm{~s}$, and $72{ }^{\circ} \mathrm{C}$ for $40 \mathrm{~s} / 1 \mathrm{~min}$; followed by $10 \mathrm{~min}$ at $72{ }^{\circ} \mathrm{C}$ for the final extension. Processing and sequencing of the PCR products were consistent with the aforementioned methods. 
Table 2. Primers used in PeTrxl cloning, expression, and recombinant analysis.

\begin{tabular}{|c|c|c|}
\hline Primer Name & Primer Sequence $\left(5^{\prime}-3^{\prime}\right)$ & Description \\
\hline PeTrxl-F1 & GCCAGGGTGTATCTGCCAT & PCR \\
\hline PeTrxl-F2 & TTATGGTGGAGAAGAGGAGG & PCR \\
\hline PeTrxl-R1 & TCTCTTCATCTCССTGGTTAT & PCR \\
\hline PeTrxl-R2 & TGGTTGTGCTAATCGGACT & PCR \\
\hline $3^{\prime}$ PeTrxl-F1 & CTATTTGTGAGGGATAACCAGGGAG & $3^{\prime} \mathrm{RACE}$ \\
\hline $3^{\prime}$ PeTrxl-F2 & CCTTGGACTTGGATAAGGCAGAAG & $3^{\prime} \mathrm{RACE}$ \\
\hline $5^{\prime}$ PeTrxl-R1 & CATTGGCCTCСTCTTCTCCACCAT & $5^{\prime} \mathrm{RACE}$ \\
\hline $5^{\prime}$ PeTrxl-R2 & TTCACAGCCAGATTTGTTCAGCATG & $5^{\prime} \mathrm{RACE}$ \\
\hline PeTrxl-F & GCAACAAAGTCAAGGTGGATTC & qPCR \\
\hline PeTrxl-R & CAGCCAGATTTGTTCAGCATG & qPCR \\
\hline GAPDH-F & CCAGAACATCATCCCAGCA & Reference gene \\
\hline GAPDH-R & ACGAACAGGGACACGGAAG & Reference gene \\
\hline$r P e \operatorname{Trxl}-\mathrm{F}$ & CGCGGATCCATGCCAGTAATTTCCATAG & Recombinant $P e$ Trxl protein \\
\hline$r P e \operatorname{Trxl}-\mathrm{R}$ & CCGCTCGAGGTGTGCTTCCCCCTTT & Recombinant $P e T r x l$ protein \\
\hline
\end{tabular}

\subsection{Sequence Analysis}

The ORF was predicted using the NCBI online tool ORFfinder (http:/ / www.ncbi.nlm. nih.gov/Structure/cdd/wrpsb.cgi, accessed 20 April 2021), whereas protein translation was evaluated using the Sequence Manipulation Suite (http:/ / www.bio-soft.net/sms/, accessed 10 May 2021). The conserved domain of PeTrxl was analyzed using the NCBI conserved domain search (http:/ / www.ncbi.nlm.nih.gov/Structure/cdd/wrpsb.cgi, accessed 10 May 2021). The molecular weight and isoelectric point were calculated using the ProtParam tool (http:/ / web.expasy.org/protparam/, accessed 10 May 2021). Potential signal peptides were determined using the SignalP-5.0 server (http:/ / www.cbs.dtu.dk/services/ SignalP/, accessed 10 May 2021). Secondary structure prediction was performed using the NPS@ server (https:/ /npsa-prabi.ibcp.fr/, accessed 10 May 2021), and the 3D structure of PeTrxl was built using I-TASSER (https: / / zhanglab.ccmb.med.umich.edu/I-TASSER/, accessed 10 May 2021). PeTrxl protein subcellular localization was predicted using WoLF PSORT (https: / / wolfpsort.hgc.jp/, accessed 10 May 2021). Vector NTI 11.5 (Invitrogen, CA, USA) and Mega 7 (Informar Technologies, Los Angeles, CA, USA) software were used for protein multiple sequence alignment and construction of the amino acid sequence phylogenetic tree, respectively. The amino acid sequences of the Trxl protein discussed in our study were downloaded from NCBI; these included those of H. sapiens (NP_004777.1), M. musculus (NP_058072.2), G. gallus (XP_424463.1), Grus americana (NWH20363.1), Chelonia mydas (XP_027673520.1), Python bivittatus (XP_007421287.1), X. tropicalis (NP_001006844.1), D. rerio (NP_957432.2), Oncorhynchus kisutch (XP_020330971.1), Strongylocentrotus purpuratus (XP_786407.1), D. pulex (EFX89451.1), Eurytemora affinis (XP_023346225.1), C. virginica (XP_022309459.1), Crassostrea gigas (XP_011425198.2), A. californica (XP_005111329.1), P. canaliculata (XP_025084263.1), and N. vectensis (XP_001633915.1).

\subsection{Tissue Distribution and Expression Differences}

RT-PCR and RT-qPCR were performed to analyze the distribution of PeTrxl in different tissues. Its distribution in the coelomic fluid, intestine, body wall, retractor muscle, and nephridium was detected using a RT-PCR program (pre-denaturation at $94{ }^{\circ} \mathrm{C}$ for $5 \mathrm{~min}$; 30 cycles at $94{ }^{\circ} \mathrm{C}$ for $30 \mathrm{~s}, 59^{\circ} \mathrm{C}$ for $30 \mathrm{~s}, 72{ }^{\circ} \mathrm{C}$ for $30 \mathrm{~s}$; final extension at $72{ }^{\circ} \mathrm{C}$ for $10 \mathrm{~min}$ ). PCR products were separated using $1 \%$ agarose gel electrophoresis; visual images were obtained using a gel image analysis system (FR, Shanghai, China). The RT-qPCR assay was conducted using the LightCycler480 II instrument (Roche, Basel, Basel-Stadt, Switzerland) to detect PeTrxl tissue distribution and expression differences. The $20 \mu \mathrm{L}$ reaction system contained $5 \mu \mathrm{L}$ of diluted cDNA, $10 \mu \mathrm{L}$ of $2 \times$ RealStar Green Fast Mixture (GenStar, Beijing, China), $3 \mu \mathrm{L}$ of $\mathrm{ddH}_{2} \mathrm{O}$, and $1 \mu \mathrm{L}$ of each primer. The RT-qPCR assay program was as follows: $95^{\circ} \mathrm{C}$ for $5 \mathrm{~min}$ and 40 amplification cycles $\left(95^{\circ} \mathrm{C}\right.$ for $15 \mathrm{~s}, 59^{\circ} \mathrm{C}$ for $15 \mathrm{~s}, 72^{\circ} \mathrm{C}$ for $15 \mathrm{~s}$, and $72{ }^{\circ} \mathrm{C}$ for $1 \mathrm{~s}$ to collect the fluorescence signal). The GAPDH gene was used as the 
internal control, based on Su et al. [65]. The RT-qPCR primers used are listed in Table 2. The comparative $2^{-\Delta \Delta C t}$ method was used to analyze the relative expression levels of PeTr $x l$ mRNA, presented as the mean \pm standard deviation (SD). Significant differences $(p<0.05)$ were analyzed using one-way ANOVA (with least significance difference (LSD) post hoc tests and Duncan post hoc tests) with SPSS 20.0 software (IBM Corporation, Armonk, NY, USA).

\subsection{Recombinant Plasmid Construction and Protein Expression}

The PeTrxl-coding region was amplified using specific primers with restriction sites (BamHI and XhoI) (Table 2). After digestion with BamH I and Xho I (Thermo Fisher Scientific, Waltham, MA, USA), the PCR product was ligated with a pET28a (+) vector (Solarbio, Beijing, China) digested using the same method. The recombinant plasmid was transformed into Transetta(DE3) (TransGen Biotech, Beijing, China), and positive transformants were selected and sequenced. After ensuring insertion of the coding fragment, cells were cultured in liquid medium (+Kanamycin) at $37^{\circ} \mathrm{C}$ with shaking at $220 \mathrm{rpm}$. When the $\mathrm{OD}_{600}$ value of the bacterial solution was 0.4-0.8, isopropylthiogalactoside (IPTG; Solarbio, Beijing, China) was added at a final concentration of $1 \mathrm{mM}$ and cells were cultured at $37^{\circ} \mathrm{C}$ and $220 \mathrm{rpm}$ for $8 \mathrm{~h}$ to induce PeTrxl expression.

\subsection{Purification and Renaturation of Recombinant PeTrxl Protein}

Following centrifugation of the induced bacterial solution, target cells were harvested and purified using HisTrap Ni-Agarose Resin (Cowin Biotech, Beijing, China), according to the manufacturer's instructions. In addition, Triton X-100 (Solarbio, Beijing, China) was used to remove the endotoxin. Recombinant PeTrxl ( $r$ PeTrxl) was refolded via dialysis renaturation. Briefly, MD34 (8000-14,000 D) dialysis membranes (Solarbio, Beijing, China) were used to dialyze the recombinant protein in a $50 \mathrm{mM}$ phosphate-buffered saline (PBS) solution containing 6, 4, 3, 2, 1, and $0 \mathrm{M}$ (three times) urea (Solarbio, Beijing, China) for $12 \mathrm{~h}$ in sequence. In addition, all concentrations of urea, excluding $0 \mathrm{M}$, were supplemented with 10\% glycerin (Solarbio, Beijing, China), 2 mM GSH (Solarbio, Beijing, China), and 0.02 mM GSSG (L-GSH oxidized; Solarbio, Beijing, China) to improve refolding efficiency in the dialysate. Refolded $r P e$ Trxl was concentrated using poly(ethylene glycol) 20,000 (Solarbio, Beijing, China). Finally, the Bradford protein assay kit (Beyotime, Shanghai, China) was used to measure the protein concentration; protein bands were separated using 10\% SDS-PAGE. Visible protein bands were obtained by staining with Coomassie Brilliant Blue R250 (Solarbio, Beijing, China).

In order to investigate the refolding efficiency of $r P e \operatorname{Trxl}$, circular dichroism measurement was performed by Jasco J-1500 spectropolarimeter (Jasco, Tokyo, Japan) with $1 \mathrm{~mm}$ path length cuvette at $20^{\circ} \mathrm{C}$. The $r P e T r x l$ was scanned at the wavelength range of 190-260 $\mathrm{nm}$ with a speed of $100 \mathrm{~nm} / \mathrm{min}$ to collect circular dichroism spectral data. The data integration time was set to $1 \mathrm{~s}$, data pitch to $0.1 \mathrm{~nm}$, bandwidth to $1 \mathrm{~nm}$. Scan each sample three times and take the average value as the final result. The secondary structure elements of $r P e \operatorname{Trxl}$ were estimated using SpectraManager software (Jasco, Tokyo, Japan).

\subsection{In Vitro Refolded rPeTrxl Activity Assay}

\subsubsection{Insulin Disulfide Reduction Assay}

The antioxidant activity of refolded $r P e \operatorname{Trxl}$ was detected using an insulin disulfide reduction assay (Holmgren, 1979), in which $0.6 \mathrm{~mL}$ of the reaction mixture was composed of $402 \mu \mathrm{L}$ of $50 \mathrm{mM}$ PBS (pH 7.4), $100 \mu \mathrm{L}$ of $2 \mathrm{mg} / \mathrm{mL}$ insulin (bovine; Solarbio, Beijing, China), $12 \mu \mathrm{L}$ of $10 \mathrm{mM}$ EDTA (Solarbio, Beijing, China), $6 \mu \mathrm{L}$ of $100 \mathrm{mM}$ DTT (Solarbio, Beijing, China), and $80 \mu \mathrm{L}$ of different final concentrations of refolded $r$ PeTrxl, including 5, 15, 30, 60, and $120 \mu \mathrm{g} / \mathrm{mL}$. All drugs were dissolved in $50 \mathrm{mM}$ PBS. For the control, refolded $r P e \operatorname{Trxl}$ was replaced with an equal volume of $50 \mathrm{mM}$ PBS; the negative control was the solution without $r P e \operatorname{Trxl}$ and DTT. The reaction was initiated by adding $6 \mu \mathrm{L}$ of $100 \mathrm{mM}$ DTT, and the reaction mixture was incubated at $25^{\circ} \mathrm{C}$ for $80 \mathrm{~min}$. Absorbance $(\mathrm{Ab})$ 
of the precipitate, via insulin reduction, was monitored at $650 \mathrm{~nm}$ every $5 \mathrm{~min}$ (Microplate Reader: Spectra Max 190; Molecular Devices, Silicon Valley, CA, USA). All samples were used in triplicate; data are presented as mean $\pm \mathrm{SD}$.

\subsubsection{ABTS Radical Scavenging Assay}

The total antioxidant capacity assay kit, along with the rapid ABTS method (Beyotime, Shanghai, China), was used to determine the ABTS radical (ABTS ${ }^{+\cdot}$ ) scavenging ability of refolded $r P e$ Trxl, according to the manufacturer's protocol. Briefly, different concentrations $(0.1,0.2,0.3,0.4$, and $0.5 \mathrm{mg} / \mathrm{mL})$ of refolded $r P e \operatorname{Trxl}$ diluents were mixed with ABTS working fluid in a 96-well plate. PBS and different concentrations $(0.1,0.2,0.3,0.4$, and $0.5 \mathrm{mg} / \mathrm{mL}$ ) of GSH were used as the negative and positive controls, respectively. The same volume of distilled water that replaced the reaction mixture was used as a blank control. Each concentration was measured in triplicate, and the Ab was monitored at $414 \mathrm{~nm}$. The $\mathrm{IC}_{50}$ was calculated using SPSS 20.0, and all data are presented as the mean $\pm \mathrm{SD}$. The ABTS radical scavenging ability (\%) of refolded $r P e \operatorname{Trxl}$ was calculated as follows:

$$
\text { ABTS radical scavenging ability }(\%)=\frac{A b_{\text {negative control }}-\mathrm{Ab}_{\text {sample }}}{A b_{\text {negative control }}-\mathrm{Ab}_{\text {blank control }}} \times 100
$$

\subsection{In Vivo Refolded rPeTrxl Activity Assay}

Injection experiments were performed to determine the effect of refolded $r P e \operatorname{Trxl}$ in vivo. Experimental groups were exposed to $1 / 2 \mathrm{Cd}-$ the $\mathrm{LC}_{50}$ and treated with an injection of refolded $r P e T r x l$, bovine serum albumin (BSA; Beyotime, Shanghai, China), $50 \mathrm{mM}$ PBS, or no injection; the control group did not receive treatment. The protein injection dose of each individual (2.5-3.5 g) was $20 \mu \mathrm{g}$ of protein per gram of body weight. After $24 \mathrm{~h}$, three individuals from each group were randomly selected for sampling. Following the collection of coelomic fluid, the ROS Assay Kit (Beyotime, Shanghai, China) was used to detect the relative concentration of ROS using flow cytometry (Becton Dickinson, San Jose, CA, USA), according to the manufacturer's instructions. The experiment was repeated with three groups of individuals. Data were analyzed using FlowJo_V10 (Ashland, OR, USA) and are presented as the mean \pm SD. Statistical analysis $(p<0.05)$ was performed using LSD and Duncan's post hoc tests in SPSS 20.0.

\section{Conclusions}

In conclusion, we cloned PeTrxl gene cDNA from P. esculenta and identified PeTrxl as a new member of the Trx superfamily. The protein encoded by the PeTrxl gene possesses antioxidant activity. Furthermore, the transcript levels of PeTrxl were significantly upregulated in the early stages of $\mathrm{Cd}$ stress, and in vivo injection of $r P e \operatorname{Trxl}$ significantly reduced the levels of intracellular ROS under Cd stress, suggesting that PeTrxl plays an important role in the defense against $\mathrm{Cd}$-induced oxidative stress. Our study provides insight for further research into the role of marine mudflat invertebrate Trxl in Cd stress. Moreover, further studies, including those elucidating the exact function and regulatory mechanism of PeTrxl in maintaining redox homeostasis in P. esculenta by gene knockout and determining the secretion pathway of $P e T r x l$, are necessary.

Author Contributions: J.M., methodology, validation, formal analysis, writing-original draft, writing-review and editing. X.G., validation, writing-review and editing. S.L., methodology. C.L., investigation. C.D., visualization. C.H., supervision. J.W., methodology, supervision. S.J., D.T., and C.Z., conceptualization. J.Z., conceptualization, methodology, supervision, funding acquisition. All authors have read and agreed to the published version of the manuscript.

Funding: This project was supported by the Ningbo Science and Technology Plan Projects (2019B10016, 2016C10004), the Major Science and Technology Projects in Zhejiang Province (2011C12013), Natural Science Foundation of Zhejiang Province (LY18C190007), and the Collaborative Innovation Center for 


\begin{abstract}
Zhejiang Marine High-efficiency and Healthy Aquaculture, and Sponsored K.C. Wong Magna Fund in Ningbo University.
\end{abstract}

Data Availability Statement: All of the data generated or analyzed during this study are included in this published article.

Conflicts of Interest: The authors declare that they have no known competing financial interests or personal relationships that could have appeared to influence the work reported in this paper.

\title{
References
}

1. Da Silva, A.O.F.; Martinez, C.B.R. Acute effects of cadmium on osmoregulation of the freshwater teleost Prochilodus lineatus: Enzymes activity and plasma ions. Aquat. Toxicol. 2014, 156, 161-168. [CrossRef]

2. Liu, J.; Qu, W.; Kadiiska, M.B. Role of oxidative stress in cadmium toxicity and carcinogenesis. Toxicol. Appl. Pharmacol. 2009, 238, 209-214. [CrossRef] [PubMed]

3. Cuypers, A.; Plusquin, M.; Remans, T.; Jozefczak, M.; Keunen, E.; Gielen, H.; Opdenakker, K.; Nair, A.R.; Munters, E.; Artois, T.J.; et al. Cadmium stress: An oxidative challenge. BioMetals 2010, 23, 927-940. [CrossRef] [PubMed]

4. Yuan, Y.; Zhang, Y.J.; Zhao, S.W.; Chen, J.; Yang, J.L.; Wang, T.; Zou, H.; Wang, Y.; Gu, J.H.; Liu, X.Z.; et al. Cadmium-induced apoptosis in neuronal cells is mediated by Fas/FasL-mediated mitochondrial apoptotic signaling pathway. Sci Rep. 2018, 8, 8837. [CrossRef] [PubMed]

5. Liu, D.M.; Yang, J.; Li, Y.J.; Zhang, M.; Wang, L. Cd-induced apoptosis through the mitochondrial pathway in the hepatopancreas of the freshwater crab Sinopotamon henanense. PLoS ONE 2013, 8, e68770.

6. Chiarelli, R.; Roccheri, M.C. Heavy metals and metalloids as autophagy inducing agents: Focus on cadmium and arsenic. Cells 2012, 1, 597-616. [CrossRef] [PubMed]

7. Lin, Y.; Huang, J.J.; Dahms, H.U.; Zhen, J.J.; Ying, X.P. Cell damage and apoptosis in the hepatopancreas of Eriocheir sinensis induced by cadmium. Aquat. Toxicol. 2017, 190, 190-198. [CrossRef]

8. Tan, H.W.; Liang, Z.L.; Yao, Y.; Wu, D.D.; Mo, H.Y.; Gu, J.; Chiu, J.F.; Xu, Y.M.; Lau, A.T.Y. Lasting DNA damage and aberrant DNA repair gene expression profile are associated with post-chronic cadmium exposure in human bronchial epithelial cells. Cells 2019, 8, 842. [CrossRef]

9. De Silva, N.A.L.; Marsden, I.D.; Gaw, S.; Glover, C.N. Acute waterborne cadmium toxicity in the estuarine pulmonate mud snail, Amphibola crenata. Ecotoxicol. Environ. Saf. 2018, 158, 274-283. [CrossRef]

10. Ji, C.; Lu, Z.; Xu, L.; Li, F.; Cong, M.; Shan, X.; Wu, H. Evaluation of mitochondrial toxicity of cadmium in clam Ruditapes philippinarum using iTRAQ-based proteomics. Environ. Pollut. 2019, 251, 802-810. [CrossRef]

11. Đukić-Ćosić, D.; Baralić, K.; Javorac, D.; Djordjevic, A.B.; Bulat, Z. An overview of molecular mechanisms in cadmium toxicity. Curr. Opin. Toxicol. 2020, 19, 56-62. [CrossRef]

12. Cao, L.; Huang, W.; Liu, J.H.; Yin, X.B.; Dou, S.Z. Accumulation and oxidative stress biomarkers in Japanese flounder larvae and juveniles under chronic cadmium exposure. Comp. Biochem. Physiol. C Toxicol. Pharmacol. 2010, 151, 386-392. [CrossRef] [PubMed]

13. Wang, J.; Zhang, H.; Zhang, T.; Zhang, R.; Liu, R.T.; Chen, Y.D. [13]s of catalase and superoxide dismutase. Int. J. Biol. Macromol. 2015, 77, 59-67. [CrossRef] [PubMed]

14. Nair, A.R.; DeGheselle, O.; Smeets, K.; Kerkhove, E.V.; Cuypers, A. Cadmium-induced pathologies: Where is the oxidative balance lost (or not)? Int. J. Mol. Sci. 2013, 3, 6116-6143. [CrossRef] [PubMed]

15. Zhang, H.J.; Cai, C.C.; Shi, C.L.; Cao, H.; Han, Z.L.; Jia, X.Y. Cadmium-induced oxidative stress and apoptosis in the testes of frog Rana limnocharis. Aquat. Toxicol. 2012, 122-123, 67-74. [CrossRef]

16. Khalid, M.U.; Qureshi, N.A.; Mubarik, M.S.; Bukhari, S.A. Heavy metals (chromium, copper and cadmium) induced oxidative stress in Labeo rohita (Hamilton, 1822) during acute and chronic toxicity experiment. Int. J. Biosci. 2015, 6, 64-72.

17. Birben, E.; Sahiner, U.M.; Sackesen, C.; Erzurum, S.; Kalayci, O. Oxidative stress and antioxidant defense. World Allergy Organ. J. 2012, 5, 9-19. [CrossRef] [PubMed]

18. Cintra, L.C.; Domingos, F.C.; Lima, Y.A.R.; Barbosa, M.S.; Santos, R.S.; Faria, F.P.; Jesuíno, R.S.A. Molecular cloning, expression and insulin reduction activity of a thioredoxin 1 homologue (Trx1) from the pathogenic fungus Paracoccidioides lutzii. Int. J. Biol. Macromol. 2017, 103, 683-691. [CrossRef]

19. Rohwer, J.M.; Viljoen, C.; Christensen, C.D.; Mashamaite, L.N.; Pillay, C.S. Identifying the conditions necessary for the thioredoxin ultrasensitive response. Perspect Sci 2016, 9, 53-59. [CrossRef]

20. Moriarty-Craige, S.E.; Jones, D.P. Extracellular thiols and thiol/disulfide redox in metabolism. Annu. Rev. Nutr. 2004, 24, 481-509. [CrossRef]

21. Dunn, L.L.; Buckle, A.M.; Cooke, J.P.; Ng, M.K. The emerging role of the thioredoxin system in angiogenesis. Arterioscler. Thromb. Vasc. Biol. 2010, 30, 2089-2098. [CrossRef]

22. Lu, J.; Holmgren, A. The thioredoxin antioxidant system. Free Radic. Biol. Med. 2014, 66, 75-87. [CrossRef] [PubMed]

23. Balsera, M.; Buchanan, B.B. Evolution of the thioredoxin system as a step enabling adaptation to oxidative stress. Free Radic. Biol. Med. 2019, 140, 28-35. [CrossRef] [PubMed] 
24. Arnér, E.S.; Holmgren, A. Physiological functions of thioredoxin and thioredoxin reductase. Eur. J. Biochem. 2000, 267, 6102-6109. [CrossRef]

25. Watson, W.H.; Yang, X.M.; Choi, Y.E.; Jones, D.P.; Kehrer, J.P. Thioredoxin and Its Role in Toxicology. Toxicol. Sci. 2004, 78, 3-14. [CrossRef]

26. Guo, N.N.; Sun, X.J.; Xie, Y.K.; Yang, G.W.; Kang, C.J. Cloning and functional characterization of thioredoxin gene from kuruma shrimp Marsupenaeus japonicus. Fish Shellfish Immunol. 2019, 86, 429-435. [CrossRef] [PubMed]

27. Lee, S.; Kim, S.M.; Lee, R.T. Thioredoxin and thioredoxin target proteins: From molecular mechanisms to functional significance. Antioxid. Redox Signal. 2012, 18, 1165-1207. [CrossRef] [PubMed]

28. Lowther, W.T.; Brot, N.; Weissbach, H.; Honek, J.F.; Matthews, B.W. Thiol-disulfide exchange is involved in the catalytic mechanism of peptide methionine sulfoxide reductase. Proc. Natl. Acad. Sci. USA 2000, 97, 6463-6468. [CrossRef] [PubMed]

29. Das, K.C.; Das, C.K. Thioredoxin, a singlet oxygen quencher and hydroxyl radical scavenger: Redox independent functions. Biochem. Biophys. Res. Commun. 2000, 277, 443-447. [CrossRef]

30. Andersen, K.M.; Madsen, L.; Prag, S.; Johnsen, A.H.; Semple, C.A.; Hendil, K.B.; Hartmann-Petersen, R. Thioredoxin Txnl1/TRP32 is a redox-active cofactor of the $26 \mathrm{~S}$ proteasome. J. Biol. Chem. 2009, 284, 15246-15254. [CrossRef]

31. Cheng, S.X.; Li, C.H.; Wang, Y.; Yang, L.M.; Chang, Y.Q. Characterization and expression analysis of a thioredoxin-like protein gene in the sea cucumber Apostichopus japonicus. Fish Shellfish Immunol. 2016, 58, 165-173. [CrossRef]

32. Liyanage, D.S.; Omeka, W.K.M.; Godahewa, G.I.; Lee, J. Molecular characterization of thioredoxin-like protein 1 (TXNL1) from big-belly seahorse Hippocampus abdominalis in response to immune stimulation. Fish Shellfish Immunol. 2018, 75, 181-189. [CrossRef] [PubMed]

33. Chen, M.N.; Zhang, J.S.; Xie, X.Z.; Wu, C.W. Cloning and functional characterization of thioredoxin genes from large yellow croaker Larimichthys crocea. Fish Shellfish Immunol. 2018, 77, 385-391. [CrossRef] [PubMed]

34. Wang, M.; Su, X.; Li, Y.; Jun, Z.; Li, T. Cloning and expression of the Mn-SOD gene from Phascolosoma esculenta. Fish Shellfish Immunol. 2010, 29, 759-764. [CrossRef] [PubMed]

35. Miranda-Vizuete, A.; Spyrou, G. Genomic structure and chromosomal localization of human thioredoxin-like protein gene (txl). DNA Seq. 2000, 10, 419-424. [CrossRef]

36. Ditgen, D.; Anandarajah, E.M.; Hansmann, J.; Winter, D.; Schramm, G.; Erttmann, K.D.; Liebau, E.; Brattig, N.W. Multifunctional thioredoxin-like protein from the gastrointestinal parasitic nematodes Strongyloides ratti and Trichuris suis affects mucosal homeostasis. J. Parasitol Res. 2016, 2016, 8421597. [CrossRef]

37. Hu, J.H.; Zhang, F.Y.; Jiang, K.J.; Fang, Y.B.; Wang, J.; Zhao, M.; Qiao, Z.G.; Ma, L.B. Molecular characterization of thioredoxin-1 and thioredoxin reductase activity in mud crab Scylla paramamosain. Genet. Mol. Res. 2014, 13, 10241-10255. [CrossRef]

38. Gleason, F.K.; Holmgren, A. Thioredoxin and related proteins in procaryotes. FEMS Microbiol. Rev. 1988, 4, 271-297. [CrossRef]

39. Wiseman, R.L.; Chin, K.T.; Haynes, C.M.; Stanhill, A.; Xu, C.F.; Roguev, A.; Krogan, N.J.; Neubert, T.A.; Ron, D. Thioredoxinrelated protein 32 is an arsenite-regulated thiol reductase of the proteasome 19S particle. J. Biol. Chem. 2009, 284, 15233-15245. [CrossRef]

40. Bedford, L.; Paine, S.; Sheppard, P.W.; Mayer, R.J.; Roelofs, J. Assembly, structure, and function of the 26S proteasome. Trends Cell Biol. 2010, 20, 391-401. [CrossRef]

41. Winston, G.W.; Di Giulio, R.T. Prooxidant and antioxidant mechanisms in aquatic organisms. Aquat. Toxicol. 1991, 19, 137-161. [CrossRef]

42. Gomes, P.; Simão, S.; Lemos, V.; Amaral, J.S.; Soares-da-Silva, P. Loss of oxidative stress tolerance in hypertension is linked to reduced catalase activity and increased c-Jun NH2-terminal kinase activation. Free Radic. Biol. Med. 2013, 56, 112-122. [CrossRef] [PubMed]

43. Kugapreethan, R.; Umasuthan, N.; Wan, Q.; Thulasitha, W.S.; Kim, C.; Lee, J. Comparative analysis of two thioredoxin-like genes in black rockfish Sebastes schlegelii and their possible involvement in redox homeostasis and innate immune responses. Dev. Comp. Immunol. 2017, 67, 43-56. [CrossRef] [PubMed]

44. Lu, W.J.; Kang, M.J.; Liu, X.F.; Zhao, X.C.; Guo, X.Q.; Xu, B.H. Identification and antioxidant characterisation of thioredoxin-like1 from Apis cerana cerana. Apidologie 2012, 43, 737-752. [CrossRef]

45. Gao, X.M.; Mu, D.L.; Hou, C.C.; Zhu, J.Q.; Jin, S.; Wang, C.L. Expression and putative functions of KIFC1 for nuclear reshaping and midpiece formation during spermiogenesis of Phascolosoma esculenta. Gene 2019, 683, 169-183. [CrossRef] [PubMed]

46. Dybas, L.K. Cellular defense reactions of Phascolosoma agassizii, a sipunculan worm: Phagocytosis by granulocytes. Biol. Bull. 1981, 161, 104-114. [CrossRef]

47. Ying, X.P.; Dahms, H.U.; Liu, X.M.; Wu, H.X.; Zhang, Y.P.; Chen, C.; Zhou, Z.M.; Zeng, G.Q.; Zhou, K.; Yang, W.X. Development of germ cells and reproductive biology in the sipunculid Phascolosoma esculenta. Aquacult. Res. 2009, 40, 305-314. [CrossRef]

48. Ying, X.P.; Sun, X.; Wu, H.X.; Dahms, H.U.; Chullasorn, S.; Zhang, Y.P.; Huang, Y.J.; Yang, W.X. The fine structure of coelomocytes in the sipunculid Phascolosoma esculenta. Micron 2010, 41, 71-78. [CrossRef]

49. Li, N.; Hou, Y.H.; Ma, D.D.; Jing, W.X.; Dahms, H.U.; Wang, L. Lead accumulation, oxidative damage and histopathological alteration in testes and accessory glands of freshwater crab, Sinopotamon henanense, induced by acute lead exposure. Ecotoxicol. Environ. Saf. 2015, 117, 20-27. [CrossRef]

50. Xia, L.; Chen, S.; Dahms, H.U.; Ying, X.; Peng, X. Cadmium induced oxidative damage and apoptosis in the hepatopancreas of Meretrix meretrix. Ecotoxicology 2016, 25, 959-969. [CrossRef] 
51. Wang, Q.; Ning, X.X.; Chen, L.L.; Pei, D.; Zhao, J.M.; Zhang, L.B.; Liu, X.L.; Wu, H.F. Responses of thioredoxin 1 and thioredoxinrelated protein 14 mRNAs to cadmium and copper stresses in Venerupis philippinarum. Comp. Biochem. Physiol. C Toxicol. Pharmacol. 2011, 154, 154-160. [CrossRef] [PubMed]

52. Zhu, Q.H.; Zhou, Z.K.; Tu, D.D.; Zhou, Y.-L.; Wang, C.; Liu, Z.P.; Gu, W.B.; Chen, Y.Y.; Shu, M.A. Effect of cadmium exposure on hepatopancreas and gills of the estuary mud crab (Scylla paramamosain): Histopathological changes and expression characterization of stress response genes. Aquat. Toxicol. 2018, 195, 1-7. [CrossRef] [PubMed]

53. Han, Y.L.; Sheng, Z.; Liu, G.D.; Long, L.L.; Wang, Y.F.; Yang, W.X.; Zhu, J.Q. Cloning, characterization and cadmium inducibility of metallothionein in the testes of the mudskipper Boleophthalmus pectinirostris. Ecotoxicol. Environ. Saf. 2015, 119, 1-8. [CrossRef] [PubMed]

54. Sheng, Z.; Yang, W.X.; Zhu J, Q. Metallothionein from Pseudosciaena crocea: Xxpression and response to cadmium-induced injury in the testes. Ecotoxicology 2015, 24, 779-794. [CrossRef] [PubMed]

55. Wu, H.; Xuan, R.; Li, Y.; Zhang, X.; Jing, W.; Wang, L. Biochemical, histological and ultrastructural alterations of the alimentary system in the freshwater crab Sinopotamon henanense subchronically exposed to cadmium. Ecotoxicology 2014, 23, 65-75. [CrossRef] [PubMed]

56. Nakamura, H.; Masutani, H.; Yodoi, J. Extracellular thioredoxin and thioredoxin-binding protein 2 in control of cancer. Semin. Cancer Biol. 2006, 16, 444-451. [CrossRef] [PubMed]

57. Hong, S.Y.; Roze, L.V.; Linz, J.E. Oxidative stress-related transcription factors in the regulation of secondary metabolism. Toxins 2013, 5, 683-702. [CrossRef]

58. Holmgren, A. Thioredoxin and glutaredoxin systems. J. Biol. Chem. 1989, 264, 13963-13966. [CrossRef]

59. De Zoysa, M.; Pushpamali, W.A.; Whang, I.; Kim, S.J.; Lee, J. Mitochondrial thioredoxin-2 from disk abalone (Haliotis discus discus): Molecular characterization, tissue expression and DNA protection activity of its recombinant protein. Comp. Biochem. Physiol. B Biochem. Mol. Biol 2008, 149, 630-639. [CrossRef]

60. Wang, G.K.; Wang, H.J.; Xiong, X.C.; Chen, S.L.; Zhang, D.Y. Mitochondria thioredoxin's backup role in oxidative stress resistance in Trichoderma reesei. Microbiol. Res. 2015, 171, 32-38. [CrossRef]

61. Kang, T.; Wan, H.; Zhang, Y.; Shakeel, M.; Lu, Y.; You, H.; Lee, K.S.; Jin, B.R.; Li, J. Comparative study of two thioredoxins from common cutworm (Spodoptera litura): Cloning, expression, and functional characterization. Comp. Biochem. Physiol. B Biochem. Mol. Biol 2015, 182, 47-54. [CrossRef] [PubMed]

62. Li, F.M.; Liang, Y.J.; Cai, J.L.; Shi, Y.J.; Ma, L.Y.; Lu, Y.Z. EsTrx-2, the mitochondrial thioredoxin from Antarctic microcrustacean (Euphausia superba): Cloning and functional characterization. Comp. Biochem. Physiol. B Biochem. Mol. Biol 2019, $231,52-58$. [CrossRef] [PubMed]

63. Nickel, W. The mystery of nonclassical protein secretion. A current view on cargo proteins and potential export routes. Eur. J. Biochem. 2003, 270, 2109-2119. [CrossRef] [PubMed]

64. Matsuo, Y.; Yodoi, J. Extracellular thioredoxin: A therapeutic tool to combat inflammation. Cytokine Growth Factor Rev. 2013, 24, 345-353. [CrossRef] [PubMed]

65. Su, X.R.; Du, L.L.; Li, Y.Y.; Li, Y.; Zhou, J.; Li, T.W. Cloning and expression of HSP70 gene of sipuncula Phascolosoma esculenta. Fish Shellfish Immunol. 2010, 28, 461-466. [CrossRef] [PubMed] 